\title{
PENGARUH PENGUNAAN PERASAN JERUK NIPIS (Citrus aurantifolia S.) TERHADAP MUTU ORGANOLEPTIK SATE DAGING KAMBING
}

\author{
Rian Konuti, F. S. Ratulangi*, J. E. G. Rompis, D. B. J. Rumondor \\ Fakultas Peternakan Universitas Sam Ratulangi Manado 95115
}

\begin{abstract}
ABSTRAK
Tujuan penelitian ini untuk mengetahui mengetahui pengaruh pengunaan perasan jeruk nipis terhadap mutu organoleptik sate daging kambing. Bahan yang digunakan adalah daging kambing bagian paha belakang, jeruk nipis dan peralatan yang dibutukan. Perlakuannya adalah R0 : 600 gram daging kambing direndam pada $0 \mathrm{~mL}$ perasan jeruk nipis selama 30 menit, R1 : 600 gram daging kambing direndam pada $5 \mathrm{ml}$ perasan jeruk nipis selama 30 menit, R2 : 600 gram daging kambing direndam pada $10 \mathrm{~mL}$ perasan jeruk nipis selama 30 menit, R3 : 600 gram daging kambing direndam pada $15 \mathrm{~mL}$ perasan jeruk nipis selama 30 menit dan R4 : 600 gram daging kambing direndam pada $20 \mathrm{~mL}$ perasan jeruk nipis selama 30 menit. Penelitian ini mengunakan Rancangan Acak Lengkap (RAL) dengan 5 taraf perlakuan dengan ulangan terdiri dari 35 panelis untuk mengetahui mutu organoleptik sate daging kambing. Variabel yang di amati adalah warna, aroma, rasa dan keempukan. Hasil penelitian ini menunjukan bahwa perlakuan memberikan pengaruh berbeda nyata $(\mathrm{P}<0,05)$ terhadap warna, aroma, keempukan dan rasa. Kesimpulan penggunaan perasan jeruk nipis dengan konsentrasi $20 \mathrm{~mL}$ dapat memberikan tingkat penerimaan mutu organoleptik warna, aroma, keempukan dan rasa sate daging kambing.
\end{abstract}

Kata kunci : Daging kambing, jeruk nipis, sate, mutu organoleptik

*Korespondensi (corresponding Author)

Email: fsratulangi@ymail.com

\section{ABSTRACT}

THE EFFECT OF LIME ((Citrus
aurantifolia S.) JUICE LEVELS ON
THE ORGANOLEPTIC QUALITY OF
GOAT MEAT SATAY. The aim of this research is to know the effect of lime juice levels on the organoleptic quality of goat meat satay. Material used on this research were the whole thigh of goat (silver side part, outside part, outside flat part, eye round part) and limes. Randomized completely design (RCD) was used on this research with five treatments as follow: $\mathrm{R} 0=600$ gram dice cut meat (without lime), $\mathrm{R} 1=600$ gram dice cut meat (marinated in 5 $\mathrm{mL}$ lime juice for 30 minutes, $\mathrm{R} 2=600$ gram dice cut meat (marinated in $10 \mathrm{~mL}$ lime juice for 30 minutes, $\mathrm{R} 3=600$ gram dice cut meat (marinated in $15 \mathrm{~mL}$ lime juice for 30 minutes, and $\mathrm{R} 4=600$ gram dice cut meat (marinated in $20 \mathrm{~mL}$ lime juice for 30 minutes, and there were 35 repetitions (panelists) each treatment. Measurements taken were color, odor, taste, and tenderness of the goat meat satay. It was found on this research that, there were significant effects of treatment (lime juice) $(\mathrm{P}<0,05)$ on color, odor, tenderness, and taste of goat meat satay. It was concluded on this research that the preference level (Organoleptic quality) of lime juice on goat meat satay was $20 \mathrm{~mL}$.

Keywords: Goat meat, lime, satay, organoleptic quality 


\section{PENDAHULUAN}

Konsumsi daging kambing di Indonesia meningkat seiring dengan pertumbuhan dan perkembangan penduduk serta bertambahnya pengetahuan dan daya beli masyarakat. Permintaan terhadap kambing cukup tinggi karena selain untuk dikonsumsi harian juga dibutuhkan dalam hari raya qurban bagi umat Islam di Indonesia setiap tahun. Daging kambing dikonsumsi dalam bentuk olahan seperti sate, sop, soto, gulai, tongseng dan sebagainya yang dijajakan di hotel berbintang, rumah makan dan pinggir jalan. Indonesia adalah negeri asal mula sate, dan hidangan ini dikenal luas hampir seluruh wilayah di Indonesia dan dianggap sebagai masakan nasional dan salah satu hidangan terbaik Indonesia. Sate merupakan hidangan yang sangat populer di Indonesia, dengan berbagai suku bangsa dan tradisi seni memasak telah menghasilkan berbagai jenis sate. Indonesia memiliki jenis sate paling banyak di dunia. Sate Indonesia biasanya dinamakan berdasarkan tempat asal resep sate, jenis daging, bahan, dan proses pembuatannya. Beberapa jenis sate khas daerah di Indonesia yaitu sate Madura, sate Padang, sate Ponorogo, sate Blora, sate Banjar, sate Makassar, sate kambing, sate kelinci dan sate lilit. Sate daging kambing memang disukai banyak orang atau konsumen, namun sate daging kambing tidak hanya memiliki keunggulan banyak disukai tapi juga mempunyai kelemahan terutama pada aroma daging kambing yang kurang disukai.

Air jeruk nipis memiliki unsurunsur senyawa kimia sehingga dapat menutupi bau khas dari daging kambing. Jeruk nipis mengandung unsur-unsur senyawa kimia seperti asam sitrat, asam amino, minyak atsiri, damar, glikosida, asam sitrun, lemak, kalsium, fosfor, besi, belerang vitamin B1 dan vitamin C, sehingga perasan jeruk nipis berpotensi untuk menghilangkan bau pada daging. Penelitian ini dilakukan untuk mengetahui konsentrasi perasan jeruk nipis yang tepat untuk menghilangkan bau amis pada daging kambing yang akan diolah menjadi sate daging kambing.

Penilaian organoleptik meliputi warna, aroma, keempukan dan rasa merupakan suatu cara penilaian yang umum dilakukan serta dijadikan alat penilaian dalam laboratorium. Penilaian organoleptik dapat digunakan untuk menentukan kualitas dan membuat keputusan dalam mengkonsumsi sate daging kambing. Berdasarkan penjelasan di atas telah dilakukan penelitian penggunaan jeruk nipis terhadap sifat mutu organoleptik sate daging kambing. 


\section{MATERI DAN METODE PENELITIAN}

\section{Materi Penelitian}

Bahan yang digunakan adalah daging kambing bagian paha belakang sebanyak $\quad \pm 3000 \mathrm{~g}$ dengan satu perlakuan mengunakan \pm 600 gram daging dipotong dengan ukuran $\pm 2 \times 2 \times 1 \mathrm{~cm}$ dengan berat satu potong \pm 4 gram, jeruk nipis (Citrus aurantifolia S.) yang setengah matang. Peralatan yang dibutukan pisau, tusuk sate, arang kayu, alat ukur (mistar), alat tulis, baskom, piring, termometer, gelas ukur, masker, pipet, aquades, dan tisue.

\section{Metode Penelitian}

Penelitian ini menggunakan rancangan acak lengkap (RAL) dengan 5 taraf perlakuan (Steel and Torrie, 1995), dengan ulagan terdiri dari 35 panelis tidak terlatih (Rahayu, 2001). Perlakuan adalah perendaman daging dalam jeruk nipis (Citrus aurantifolia $S$.) yang terdiri dari 5 taraf perlakuan yakni :

$\mathrm{R} 0=600$ gram daging kambing direndam pada $0 \mathrm{~mL}$ perasan jeruk nipis selama 30 menit

$\mathrm{R} 1=600$ gram daging kambing direndam pada $5 \mathrm{~mL}$ perasan jeruk nipis selama 30 menit
$\mathrm{R} 2=600$ gram daging kambing direndam pada $10 \mathrm{~mL}$ perasan jeruk nipis selama 30 menit

$\mathrm{R} 3=600$ gram daging kambing direndam pada $15 \mathrm{~mL}$ perasan jeruk nipis selama 30 menit

$\mathrm{R} 4=600$ gram daging kambing direndam pada $20 \mathrm{~mL}$ perasan jeruk nipis selama 30 menit

\section{Variabel Yang Di amati}

Variabel yang diamati adalah mutu organoleptik daging yaitu warna, aroma, keempukan dan rasa (format uji dapat dilihat pada lampiran 1). Penelitian ini menggunakan uji organoleptik dengan skala hedonik 1 sampai 7, panelis yang digunakan adalah panelis tidak terlatih yaitu 35 orang (Rahayu, 2001). Skala hedonik yang digunakan untuk uji warna skor 7 = sangat menarik sekali, $6=$ sangat menarik, $5=$ agak sangat menarik, $4=$ menarik, 3 = agak tidak menarik, 2 = tidak menarik, 1 = sangat tidak menarik. Skor aroma 7 = sangat suka sekali, $6=$ sangat suka, 5 = agak sangat suka, $4=$ suka, $3=$ agak tidak suka, 2 = tidak suka, 1 = sangat tidak suka. Skor keempukan $7=$ sangat empuk sekali, $6=$ sangat empuk, 5 = agak sangat empuk, 4 = empuk, 3 = agak tidak empuk, 2 = tidak empuk, 1 = sangat tidak empuk. Rasa skor 7 = sangat enak sekali, 6 = sangat enak, 5 = agak sangat enak, $4=$ 
enak, 3 = agak tidak enak, 2 = tidak enak, 1 $=$ sangat tidak enak

\section{Prosedur Penelitian}

Daging kambing bagian paha belakang sebanyak $3000 \mathrm{~g}$ dibeli di pasar Bersehati Manado. Daging kambing yang sudah dipisahkan dari tulang, kemudian dipotong berbentuk kotak dengan ukuran $2 \times 2 \times 1 \mathrm{~cm}$ dengan berat satu potongan daging kambing $4 \mathrm{~g}$. Dalam satu perlakuan mengunakan daging kambing sebanyak $600 \mathrm{~g}$, dilumuri dengan perasan air jeruk nipis dengan konsentrasi $0 \mathrm{~mL}, 5 \mathrm{~mL}, 10$ $\mathrm{mL}, 15 \mathrm{~mL}, 20 \mathrm{~mL}$ kemudian diaduk-aduk dan didiamkan selama 30 menit. Daging yang sudah direndam dalam perasan air jeruk nipis ditusuk searah dengan serat daging mengunakan tusuk sate dari bambu dalam 1 tusuk terdiri dari 4 potong daging dengan lama pemanggangan 5 menit dengan jarak bara api $10 \mathrm{~cm}$ dan suhu pemanggangan sate $77,31{ }^{\circ} \mathrm{C}$ (Taufik, 2006). Kemudian dilakukan uji organoleptik dengan 35 panelis tidak terlatih. Pembuatan sate kambing dapat dilihat pada diagram alir (Gambar 1).

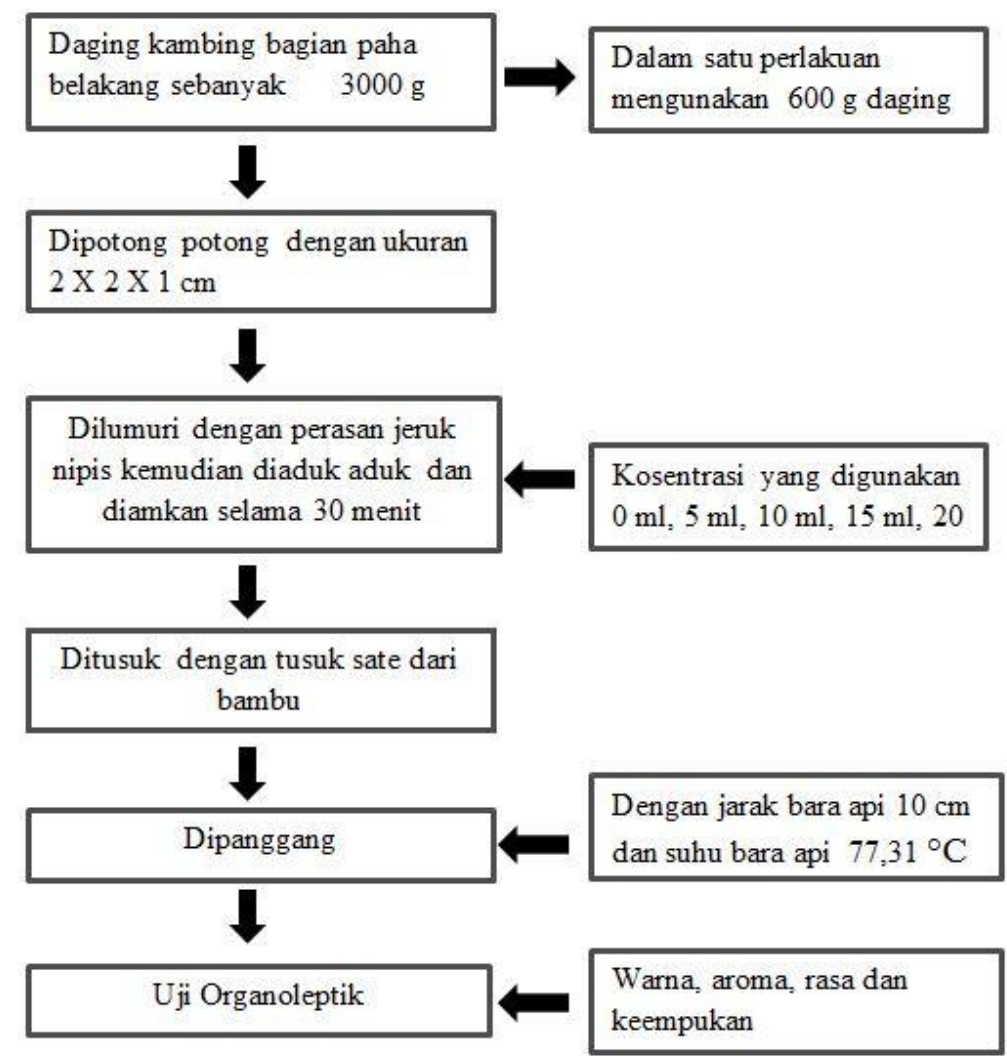

Gambar 1. Diagram alir pembuatan sate daging kambing 


\section{Analisis Data}

Hasil mutu hedonik ditabulasi data respon dari skala hedonik ke numerik dan data yang diperoleh dianalisa dengan analisa keragaman (analisis of variance) atau mengunakan Mini Tab versi 16 dilanjutkan dengan uji lanjut beda nyata jujur (BNJ).

\section{HASIL DAN PEMBAHASAN}

Hasil pengamatan pengaruh penggunaan jeruk nipis (Citrus aurantifolia $S$.) terhadap mutu organoleptik sate daging kambing, selama penelitian disajikan pada Tabel 1.

\section{Warna Sate Daging Kambing}

Hasil pengamatan untuk pengaruh penggunaan jeruk nipis (Citrus aurantifolia
S.) terhadap warna sate daging kambing, dapat dilihat pada Tabel 1. Data tersebut menujukan bahwa tingkat kesukaan panelis terhadap warna sate daging kambing dengan kosentrasi perasan jeruk nipis (Citrus aurantifolia S.) yang berbeda, terdapat pada kisaran rataan 3,51 (menarik) sampai 4,91 (agak sangat menarik).

Hasil sidik ragam menunjukan bahwa perlakuan pengunaan jeruk nipis (Citrus aurantifolia S.) memberikan pengaruh berbeda nyata $(\mathrm{P}<0,05)$ terhadap warna sate daging kambing. Hasil uji lanjut menggunakan Uji Beda Nyata Jujur menunjukan bahwa perlakuan tanpa pengunaan jeruk nipis tidak berbeda nyata $(\mathrm{P}>0,05)$ terhadap perlakuan $5 \mathrm{~mL}$ tetapi berbeda nyata $(\mathrm{P}<0,05)$ terhadap perlakuan $10 \mathrm{~mL}, 15 \mathrm{~mL}$ dan $20 \mathrm{~mL}$. Perlakuan $5 \mathrm{~mL}$ tidak berbeda nyata $(\mathrm{P}>0,05)$ terhadap perlakuan $10 \mathrm{~mL}$ tetapi berbeda nyata

Tabel 1. Rataan Pengaruh Perasan Jeruk Nipis (Citrus aurantifolia Swingle) Terhadap Mutu Organoleptik Sate Daging Kambing

\begin{tabular}{llllll}
\hline \multirow{2}{*}{ Variabel } & \multicolumn{4}{c}{ Perlakuan Penggunaan Jeruk Nipis } \\
\cline { 2 - 6 } & $0 \mathrm{~mL}$ & $5 \mathrm{~mL}$ & $10 \mathrm{~mL}$ & $15 \mathrm{~mL}$ & $20 \mathrm{~mL}$ \\
\hline Warna & $3,51^{\mathrm{a}}$ & $3,71^{\mathrm{ab}}$ & $4,00^{\mathrm{bc}}$ & $4,42^{\mathrm{c}}$ & $4,91^{\mathrm{d}}$ \\
Aroma & $3,91^{\mathrm{a}}$ & $4,48^{\mathrm{b}}$ & $4,74^{\mathrm{bc}}$ & $4,88^{\mathrm{bc}}$ & $5,14^{\mathrm{c}}$ \\
Keempukan & $5,14^{\mathrm{a}}$ & $4,85^{\mathrm{a}}$ & $4,74^{\mathrm{a}}$ & $4,22^{\mathrm{b}}$ & $3,97^{\mathrm{b}}$ \\
Rasa & $3,17^{\mathrm{a}}$ & $4,14^{\mathrm{ab}}$ & $4,51^{\mathrm{bc}}$ & $4,77^{\mathrm{cd}}$ & $5,14^{\mathrm{d}}$ \\
\hline
\end{tabular}

Keterangan : Superskrip berbeda pada baris yang sama artinya berbeda nyata $(\mathrm{P}<0,05)$ 
$(\mathrm{P}<0,05)$ terhadap perlakuan $15 \mathrm{~mL}$ dan 20 mL. Perlakuan $10 \mathrm{~mL}$ tidak berbeda nyata $(\mathrm{P}>0,05)$ terhadap perlakuan $15 \mathrm{~mL}$ tetapi berbeda nyata $(\mathrm{P}<0,05)$ terhadap perlakuan $20 \mathrm{~mL}$. Perlakuan $15 \mathrm{~mL}$ berbeda nyata $(\mathrm{P}<0,05)$ terhadap perlakuan $20 \mathrm{~mL}$. Dari data yang dihasilkan semakin tinggi kosentrasi semakin memberikan pengaruh pada daging. Menurut Purnamasari et al. (2013) kosentrasi asam sitrat yang besar dan banyak mengandung senyawa asam dapat menghasilkan warna memucat pada daging. Warna yang menarik akan meningkatkan penerimaan produk. Hasil warna sate daging kambing menujukan warna agak kecoklatan sampai coklat, hasil ini sesuai dengan hasil penelitian yang dilakukan oleh (Adiyastiti et al., 2014). Hal ini dapat disebabkan oleh glikosida dan protein dalam jeruk nipis (Citrus aurantifolia S.). Warna coklat pada sate daging kambing disebabkan karena dalam jeruk nipis (Citrus aurantifolia $S$.) memiliki kandungan protein dan senyawa glikosida sehingga terjadi reaksi maillard. Reaksi maillard adalah reaksi antara protein dengan gula pereduksi (Muchtadi dan Sugiono, 1992).

\section{Aroma Sate Daging Kambing}

Hasil pengamatan untuk pengaruh penggunaan jeruk nipis (Citrus aurantifolia $S)$ terhadap aroma sate daging kambing, dapat dilihat pada Tabel 1. Rataan tingkat kesukaan panelis terhadap aroma sate daging kambing berkisar antara 3,91 (suka) sampai 5,14 (agak sangat suka).

Hasil sidik ragam menunjukan bahwa perlakuan pengunaan jeruk nipis (Citrus aurantifolia S.) memberikan pengaruh berbeda nyata $(\mathrm{P}<0,05)$ terhadap aroma sate daging kambing. Hasil uji lanjut menggunakan Uji Beda Nyata Jujur menunjukkan bahwa perlakuan $0 \mathrm{~mL}$ berbeda nyata $(\mathrm{P}<0,05) \quad$ terhadap perlakuan $5 \mathrm{~mL}, 10 \mathrm{~mL}, 15 \mathrm{~mL}$ dan $20 \mathrm{~mL}$. Perlakuan $5 \mathrm{~mL}$ tidak berbeda nyata $(\mathrm{P}>0,05)$ terhadap $10 \mathrm{~mL}, 15 \mathrm{~mL}$ tetapi berbeda nyata $(\mathrm{P}<0,05)$ terhadap $20 \mathrm{~mL}$. Perlakuan $10 \mathrm{~mL}$ tidak berbeda nyata (P>0,05) terhadap $15 \mathrm{~mL}$ dan $20 \mathrm{~mL}$. Perlakuan $15 \mathrm{~mL}$ tidak berbeda nyata $(\mathrm{P}>0,05)$ terhadap $20 \mathrm{~mL}$. Hal ini disebabkan oleh unsur-unsur senyawa pada jeruk nipis (Citrus aurantifolia S.) contohnya asam sitrat minyak atsiri yang berfungsi untuk rasa dan aroma makanan. Semakin tinggi kosentrasi perasan jeruk nipis (Citrus aurantifolia S.) maka semakin banyak unsur-unsur senyawa jeruk nipis (Citrus aurantifolia S.) yang meresap sehingga mempengaruhi aroma sate daging kambing. Menurut Muchtadi dan Sugiono, (1992), bahwa kandungan minyak atsiri memiliki aroma yang dapat berpengaruh terhadap perubahan aroma produk yang diberi perlakuan. 


\section{Rasa Sate Daging Kambing}

Hasil pengamatan untuk pengaruh penggunaan jeruk nipis (Citrus aurantifolia S.) terhadap rasa sate daging kambing, dapat dilihat pada Tabel 1. Rataan tingkat kesukaan panelis terhadap rasa sate daging kambing berkisar antara 3,71 (enak) sampai 5,14 (agak sangat enak).

Hasil sidik ragam menunjukan bahwa perlakuan pengunaan jeruk nipis (Citrus aurantifolia S.) memberikan pengaruh berbeda nyata $(\mathrm{P}<0,05)$ terhadap rasa sate daging kambing. Hasil uji lanjut menggunakan Uji Beda Nyata Jujur menunjukan bahwa perlakuan $0 \mathrm{ml}$ tidak berbeda nyata $(\mathrm{P}>0,05)$ terhadap perlakuan $5 \mathrm{ml}$ tetapi berbeda nyata $(\mathrm{P}<0,05)$ terhadap $10 \mathrm{ml}, 15 \mathrm{~mL}$ dan $20 \mathrm{~mL}$. Perlakuan $5 \mathrm{~mL}$ tidak berbeda nyata $(\mathrm{P}>0,05)$ terhadap 10 $\mathrm{mL}$ tetapi berbeda nyata $(\mathrm{P}<0,05)$ terhadap $15 \mathrm{~mL}$ dan $20 \mathrm{~mL}$. Perlakuan $10 \mathrm{~mL}$ tidak berbeda nyata $(\mathrm{P}>0,05)$ terhadap $15 \mathrm{~mL}$ tetapi berbeda nyata $(\mathrm{P}<0,05)$ terhadap 20 $\mathrm{mL}$. Perlakuan $15 \mathrm{~mL}$ tidak berbeda nyata $(\mathrm{P}>0,05)$ terhadap $20 \mathrm{~mL}$. Dari hasil analisis data dapat diketahui bahwa semakin tinggi kosentrasi perasan jeruk nipis (Citrus aurantifolia $S$.) maka tingkat penerimaan terhadap rasa sate daging kambing semakin meningkat. Hal ini di sebabkan didalam kandungan jeruk nipis mengandung asam sitrat untuk penyedap rasa. Menurut Ovelando et al. (2013), asam sitrat adalah senyawa yang berpengaruh terhadap cita rasa dan meningkatkan cita rasa suatu produk.

\section{Keempukan Sate Daging Kambing}

Hasil pengamatan untuk pengaruh peenggunaan jeruk nipis (Citrus aurantifolia $S$.) terhadaap keempukan sate daging kambing, dapat dilihat pada tabel 1 . Rataan tingkat kesukaan panelis terhadap keempukan sate daging kambing berkisar antara 3,97 (empuk) sampai 5,14 (agak sangat empuk).

Hasil sidik ragam menunjukan bahwa perlakuan pengunaan jeruk nipis (Citrus aurantifolia S.) memberikan pengaruh berbeda nyata $(\mathrm{P}<0,05)$ terhadap keempukan sate daging kambing. Hasil uji lanjut menggunakan Uji Beda Nyata Jujur menunjukan bahwa perlakuan $0 \mathrm{~mL}$ tidak berbeda nyata $(\mathrm{P}>0,05)$ terhadap $5 \mathrm{~mL}, 10$ $\mathrm{mL}$ tetapi berbeda nyata $(\mathrm{P}<0,05)$ terhadap $15 \mathrm{~mL}$ dan $20 \mathrm{~mL}$. Perlakuan $5 \mathrm{~mL}$ tidak berbeda nyata $(\mathrm{P}>0,05)$ terhadap $10 \mathrm{~mL}$ tetapi berbeda nyata $(\mathrm{P}<0,05)$ terhadap 15 $\mathrm{mL}$ dan $20 \mathrm{~mL}$. Perlakuan $10 \mathrm{~mL}$ berbeda nyata $(\mathrm{P}<0,05)$ terhadap $15 \mathrm{~mL}$ dan $20 \mathrm{~mL}$. Perlakuan $15 \mathrm{~mL}$ tidak berbeda nyata (P>0,05) terhadap $20 \mathrm{~mL}$. Hal ini disebabkan oleh kandungan jeruk nipis (Citrus aurantifolia S.). Hasil penelitian Mickalek et al. (2001) memperlihatkan bahwa penggunaan asam sitrat yang terdapat didalam ekstrak jeruk nipis dengan 
konsentrasi $5-10 \%$ mampu memberikan cita rasa yang baik dan meningkatkan keempukan daging. Keempukan daging adalah parameter dalam menentukan kualitas daging yang diuji secara sensoris. Daging yang empuk adalah hal yang paling dicari konsumen (Komariah et al., 2004). Keempukan merupakan faktor yang mempengaruhi mutu produk terutama hubungannya dengan selera konsumen dan mempengaruhi penerimaan secara umum. Keempukan daging dapat diketahui dengan mengukur daya putusnya, semakin rendah nilai daya putusnya, semakin empuk daging tersebut (Maruddin, 2004).

\section{KESIMPULAN}

Penggunaan perasan jeruk nipis (Citrus aurantifolia S.) dengan konsentrasi 10-20 ml dapat memberikan tingkat penerimaan mutu organoleptik warna, aroma, keempukan dan rasa sate daging kambing.

\section{DAFTAR PUSTAKA}

Adiyastiti, B. E, T., E. Suryanto, dan Rusman. 2014. Pengaruh lama pembakaran dan jenis bahan bakar terhadap kualitas sensoris dan kadar benzoa (A) piren sate daging kambing. Buletin Peternakan 38(3): 189-196
Komariah, I. I. Arief dan Y. Wiguna. 2004. Kualitas fisik dan mikrobia daging sapi yang ditambah jahe (Zinger Officinaleroecoe) pada konsentrasi dan lama penyimpanan yang berbeda. Media Peternakan Vol. 27(2):46 -54.

Mickalek, J.E., F.Z. Akhtar, J.C. Arezzo, D.H. Garabrant, dan J.W. Albers. 2001. Serum dixion and paripheral neuropathy in veterans of operation ranch hand. J. Neurotoxicology 22:479-490

Maruddin, F. 2004. Kualitas daging sapi asap pada lama pengasapan dan penyimpanan. Jurnal Sains dan Teknologi Vol. 4(2):83-90.

Muchtadi,T. R. dan Sugiono. 1992. Ilmu pengetahuan bahan pangan. Departemen pendidikan dan Kebudayaan. Direktorat jendral kependidikan tinggi. Pusat antar Univesitas Pangan Dan Gizi. ITB

Ovelando R., A. Mutiara, dan H.S. Azhari. 2013. Fermentasi buah markisa (Passiflora) menjadi asam sitrat. Jurnal Teknik Kimia Vol. 19(3):1521

Purnamasari, E., P. Rifni, H. Jully. 2013. Sifat fisak daging kerbau yang direndam dengan asap cair dan asam sitrat pada kosentrasi yang berbeda.. SAGU.12(1) :1-7

Rahayu, W.P. 2001. Penuntun Praktikum Penilaian Organoleptik. Fakultas Teknologi Pertanian IPB, Bogor.

Steel, R.G.D. dan J.H.Torrie. 1995. Prinsip dan Prosedur Statistika. Penterjemah Bambang Sumantri. Gramedia Pustaka, Jakarta 
Taufik, C. 2006. Keamanan Mengkonsumsi Sate Daging Kambing Ditinjau Dari Aspek Pemanasan Dan Tingkat Cemaran Mikroba Di Kotamadya Jakarta Timur. Tesis. Sekolah Pascasarjana. Institut Pertanian Bogor. 